\title{
Assessment of Vitamin D Supplementation in People with Intellectual Disability
}

\author{
Ramón Zabalza ${ }^{1}$, Iñaki Múgica ${ }^{1}$, Fernando Sistiaga ${ }^{1}$, Adolfo Garrido², \\ José Ignacio Emparanza ${ }^{3}$ and Paul Zubillaga ${ }^{1, *}$ \\ ${ }^{1}$ Uliazpi, Villa Careaga, Calzada vieja de Ategorrieta n 95. 20013, San Sebastián, Spain \\ ${ }^{2}$ Donostia University Hospital, Biochemistry Department, Paseo Dr. Beguiristain, 20014 San Sebastián, Spain \\ ${ }^{3}$ Donostia University Hospital, Clinical Epidemiology Unit, Paseo Dr. Beguiristain, 20014 San Sebastián, \\ Spain
}

\begin{abstract}
Vitamin D levels are often lower than recommended among certain groups, and these so-called at risk populations include institutionalised people with intellectual disabilities. The administration of vitamin D supplements does normalize these levels, but they tend to fall again when treatment is discontinued. The objectives of this study were, first, to assess whether the administration of 20,000 IU of cholecalciferol monthly and 60,000 IU quarterly over a year provide similar satisfactory results, and second, to explore whether the results are associated with following variables: sex, antiepileptic medication, being a wheelchair user or able to walk, and being a resident or day care user. The study population was composed of 204 individuals of both sexes cared for in four centres of the same institution. There were no differences between the levels reached with monthly and quarterly administration. The overall results show that, at the end of the test period, total $25(\mathrm{OH})$ vitamin $\mathrm{D}$ levels were $<30 \mathrm{nmol} / \mathrm{L}$ in $3.5 \%$ of participants, 30 to $<50$ $\mathrm{nmol} / \mathrm{L}$ in $34 \%, 50$ to $<75 \mathrm{nmol} / \mathrm{L}$ in $41 \%$ and $\geq 75 \mathrm{nmol} / \mathrm{L}$ in $21.5 \%$. There were significant differences between centres. We did not observe any harmful adverse effects attributable to the treatment. To conclude, we propose the continuous systematic administration of $60,000 \mathrm{IU}$ of cholecalciferol every three months in this at-risk population.
\end{abstract}

Keywords: Intellectual disability, cholecalciferol, Vitamin D supplementation, antiepileptics, prevention.

\section{INTRODUCTION}

The term vitamin $D$ refers to the precursors of a hormone $(1,25-$ hydroxyvitamin $\mathrm{D})$. These precursors are cholecalciferol or vitamin D3 and ergocalciferol or vitamin D2. The former comes from 7dehydrocholesterol and both the vitamin and its precursor are widely distributed in animals, including humans. A small proportion is obtained from the diet but most comes from the transformation of 7dehydrocholesterol in the skin into vitamin D3 on exposure to ultraviolet light. On the other hand, vitamin D2 is present at low levels in nature and its importance lies in the fact that its synthetic products have been used as a source of vitamin for humans and animals.

The main classical function of vitamin $D$ is the regulation of calcium ( $\mathrm{Ca}$ ) homeostasis; it has been demonstrated that it prevents the development of osteoporosis and related fractures that tend to occur at advanced ages. In addition, vitamin D receptors have been found in certain organs, suggesting that it has a preventive role in infectious, autoimmune and cardiovascular diseases as well as cancer [1]. The results of a systematic review carried out to study the

*Address correspondence to these authors at the Ulizazpi, Villa Careaga, Calzada vieja de Ategorrieta $n^{\circ} 95$. 20013, San Sebastián, Spain;

Tel: 609714302; Fax: 943287355; E-mail: pzubillaga@telefonica.net relation between the cognitive function, the dementia and the levels of vitamin $D$ in adults suggest that the low concentrations of vitamin associate with a poorer cognitive function and a higher risk of Alzheimer disease [2].

Both vitamins D2 and D3 undergo mitochondrial 25hydroxylation to $25(\mathrm{OH})$ vitamin $\mathrm{D} 2$ or $25(\mathrm{OH})$ vitamin D3. These two forms represent the measurable pool of $25(\mathrm{OH})$ vitamin $\mathrm{D}$ (total $25[\mathrm{OH}] \mathrm{D}$ ), which is used as a biomarker for assessing vitamin $\mathrm{D}$ status.

\section{RATIONALE FOR THE STUDY}

Since 2007, the Uliazpi Foundation has monitored plasma levels of total $25(\mathrm{OH}) \mathrm{D}$ in individuals under its care. This monitoring is carried out through regular check-ups, in general once a year, which include a clinical examination and blood test. This is how we became aware that vitamin $\mathrm{D}$ deficiency was common in this population, more than half $(52 \%)$ of the individuals monitored having total $25(\mathrm{OH}) \mathrm{D}$ levels of less than $25 \mathrm{nmo} / \mathrm{L}$ in 2007 in the Donostia Centre. Since then, those with low levels have been treated with oral supplements of cholecalciferol. These supplements have been prescribed on a case-by-case basis and discontinued if blood levels improved. With this approach, it was commonplace that the blood levels were found to have returned to below normal in 
subsequent yearly check-ups. This prompted us to explore alternative feasible treatment regimens in our setting that might both correct the deficiency in this vitamin and keep levels within the normal range in the long term.

\section{Objectives}

1. To determine whether the administration of a single dose of $20,000 \mathrm{IU}$ of cholecalciferol every month for one year resulted in adequate plasma levels of total $25(\mathrm{OH}) \mathrm{D}$.

2. To assess whether doses of 60,000 IU every three months achieved similar results to doses of 20,000 IU every month.

3. To explore whether results were related to the following variables: sex, antiepileptic medication, being a wheelchair user or able to walk, and being a resident or day care user.

\section{SUBJECTS AND METHODS}

The study population was composed of 204 individuals of both sexes who are cared for in four centres that the Uliazpi Foundation manages in Gipuzkoa. The Ategorrieta and Donostia centres are in San Sebastián, while the Fraisoro and Zubieta centres are 20 and $24 \mathrm{~km}$ outside the city, respectively. San Sebastian is at a latitude of $43^{\circ}$ North and had a total of 1954.3 hours of sunshine in 2012. The Uliazpi Foundation, run under the auspices of the Gipuzkoa Provincial Council, cares for people with intellectual disabilities requiring a high level of continuous care.

The inclusion criteria were: being aged 18 years old or above of either sex, regularly cared for as a resident or a day care user, and fed by mouth. People who had previously been given $\mathrm{Ca}$, vitamin $\mathrm{D}$ or its derivatives or had eaten foods enriched with this vitamin in the previous two months were excluded, as were any with renal disorders, lithiasis or history of thereof, or abnormal levels of $\mathrm{Ca}$ and $\mathrm{P}$ in the routine blood tests at previous check-ups.

The study was started on $1^{\text {st }}$ December 2011 and lasted for 12 consecutive months. A total of 240 people were cared for in the centres over that period. Families/legal guardians were provided with information about the study and asked to give written informed consent.

This was an open-label, parallel-group, randomised controlled study. Randomization was carried out using a permuted block design (with a block size of 6 ), including all the patients from all four centres. Group allocation was concealed by one researcher (who did not have contact with the patients) assigning a code to each participant.

All participants were given the same commercially available formulation of cholecalciferol containing $20,000 \mathrm{IU}$ per $10 \mathrm{ml}$, one group receiving $10 \mathrm{ml}$ every month and the others $30 \mathrm{ml}$ every three months. We did not consider it necessary to have a third group that received only placebo given the objectives of the study.

The results were analysed considering the levels of $\mathrm{Ca}$, phosphorus $(\mathrm{P})$, alkaline phosphatase $(\mathrm{ALP})$ and total 25(OH)D at the end of the study. Blood samples were taken in the centres themselves during January and February 2013. The analysis of blood was performed in the Biochemistry Laboratory at Donostia University Hospital on the same day as collection of the samples. The quantification of $\mathrm{Ca}, \mathrm{P}$, and ALP was carried out using standard procedures on the Cobas 6000 platform (Roche Diagnostics). Total 25(OH) D was quantified by means of electrochemoluminiscence using the Cobas e 601 module (Roche Diagnostics). This technique identifies the D2 and D3 forms of vitamin D. It is standardized using liquid chromatography-mass spectrometry analysis and the inter-test variation coefficient $(\mathrm{CV})$ is less than $8 \%$ at various different ranges of concentration.

This study complied with current Spanish legislation on clinical trials and was approved by the Ethics Committee of Donostia Hospital and the management of the Uliazpi Foundation, as well as the families and legal guardians of participants.

\section{Statistical Methods}

The variables were described using the most suitable statistic given the nature and the measurement scale: means and standard deviations for continuous variables and absolute and relative frequencies in percentages for categorical variables.

Data were compared between groups by one-way ANOVA and the relationship between continuous variables was explored using linear regression models. In addition, to assess the effect size of various factors associated with the outcomes considered, odds ratios (and 95\% confidence intervals) were calculated using logistic regression models. The analysis was carried out on an intention-to-treat basis, using the STATA (version 12) statistical software. 


\section{RESULTS}

A total of 12 participants were lost to follow-up: 8 died for reasons not related the trial; and in 4 the treatment was discontinued: one due to prolonged hospitalization and another due to an error on transfer from one centre to another; while in the other 2 the reason was that they received extra doses of calcitriol administered by individuals not connected with the study.

All participants had moderate-to-severe intellectual disabilities, more than half at the severe end of the spectrum. In Table 1 we summarise their characteristics related to age, sex, usage of the centre (residents vs. day care users), ability to walk (those able to walk even if with difficulty vs. those who were wheelchair users all day) and whether they were on antiepileptic medication.

At the end of the study, the total 25(OH)D levels were $<30 \mathrm{nmol} / \mathrm{L}$ in 7 patients $(3.5 \%), 30$ to $<50 \mathrm{nmol} / \mathrm{L}$ in $69(34 \%), 50$ to $<75 \mathrm{nmol} / \mathrm{L}$ in $84(41 \%)$ and $\geq 75$ $\mathrm{nmol} / \mathrm{L}$ in $44(21.5 \%)$. In the first of these groups, 6 were women, 6 were residents, and all but one was able to walk, no significant differences being found in their characteristics compared to the other groups.

On the other hand, the analysis of variance taking values of total $25(\mathrm{OH}) \mathrm{D}$ (Table 2) as the dependant variable indicated that there were statistically significant differences between the centres $(p<0.05)$, the levels being lower in the Donostia than in the Fraisoro and Zubieta centres, and patients in Ategorrieta centre having lower levels than those in Zubieta. Categorising the values of total $25(\mathrm{OH}) \mathrm{D}$ using a cut-off of 50 $\mathrm{nmol} / \mathrm{L}$, the multiple logistic regression analysis of the data showed that there were statistically significant differences between the Ategorrieta and Donostia centres, compared to the Fraisoro and Zubieta centres $(p=0.001)$. The same pattern was observed setting the cut-off at $75 \mathrm{nmol} / \mathrm{L}(p=0.006)$.

Based on multiple logistic regression analysis and using the risk for the Donostia centre as the reference, the odds ratio for the Zubieta Centre was found to be 0.23 , that is, those from this centre had an almost $80 \%$ lower risk of having levels below $50 \mathrm{nmol} / \mathrm{L}$ than other participants. We did not find any differences between sexes $(p=0.26)$, between residents and day care users $(p=0.853)$, between those taking and not taking antiepileptic medication $(p=0.799)$, or between those taking the vitamin $\mathrm{D}$ supplement monthly and quarterly $(p=0.515)$. On the other hand, the wheelchair users had lower levels than those who were able to walk, although the difference was not significant $(p=0.06)$. Simple regression analysis showed that the levels of vitamin $D$ became significantly lower with higher $\mathrm{PTH}$ levels $(p=0.005)$, but were not related to levels of $\mathrm{Ca}$ $(p=0.940), P(p=0.607)$ or ALP $(p=0.204)$.

We did not find any significant differences as a function of the other variables considered, though with respect to walking, we note that more of the wheelchair users than of those able to walk had levels under 50 $\mathrm{nmol} / \mathrm{L}(51.3$ vs. $34.7 \% ; \mathrm{p}=0.06)$.

\section{DISCUSSION}

Vitamin D supplementation, that is, the intake of vitamin $\mathrm{D}$ additional to that acquired from diet and produced by exposure to sunlight, is based on the assumption that there may be cases in which vitamin $D$ levels are insufficient not only in the presence of ill health but also under what could be considered "normal" circumstances. Hence, so-called "at risk groups" have been identified. Recent studies have included, among others, people who live in institutions,

Table 1: Descriptive Data on the Study Population

\begin{tabular}{|c|c|c|c|c|c|}
\hline & \multicolumn{4}{|c|}{ Centre } & \multirow{2}{*}{ Total } \\
\hline & Ategorrieta & Donostia & Fraisoro & Zubieta & \\
\hline Number and sex (F/M) & $20(8 / 12)$ & $51(35 / 16)$ & $65(25 / 40)$ & $68(28 / 40)$ & $204(96 / 105)$ \\
\hline Mean age (SD) & $43.5(7.5)$ & $42.5(7)$ & $49.4(7.3)$ & $48.8(9.5)$ & $46.9(8.6)$ \\
\hline Resident/Day care & $10 / 10$ & $44 / 7$ & $59 / 6$ & $59 / 9$ & $182 / 22$ \\
\hline Walk: Yes/No & $14 / 6$ & $40 / 11$ & $54 / 11$ & $59 / 9$ & $167 / 37$ \\
\hline Medication taken: Yes/No & $15 / 5$ & $41 / 10$ & $60 / 5$ & $63 / 5$ & $179 / 25$ \\
\hline Antiepileptics taken: Yes/No & $12 / 8$ & $27 / 24$ & $42 / 23$ & $34 / 34$ & $115 / 89$ \\
\hline $\begin{array}{l}\text { Vitamin Supplement: } \\
\text { Monthly/Quarterly }\end{array}$ & $10 / 10$ & $26 / 25$ & $34 / 31$ & $33 / 35$ & $103 / 101$ \\
\hline
\end{tabular}


Table 2: Results: Relationship between Total 25(OH) Vitamin D (nmol/L) Levels and the other Variables Studied

\begin{tabular}{|c|c|c|}
\hline Categorical variables & Mean total 25(OH) D level (SD) & p \\
\hline $\begin{array}{l}\text { Centre: } \\
\text { - Ategorrieta } \\
\text { - Donostia } \\
\text { - Fraisoro } \\
\text { - Zubieta }\end{array}$ & $\begin{array}{c}52.37(20.37) \\
47.57(20.67) \\
60.7(20.8) \\
68.82(20.65)\end{array}$ & $<0.05$ \\
\hline $\begin{array}{l}\text { Usage of centre: } \\
\text { Day care user } \\
\text { Resident }\end{array}$ & $\begin{array}{l}58.47(21.87) \\
59.42(22.52)\end{array}$ & 0.85 \\
\hline $\begin{array}{l}\text { Antiepileptics: } \\
\text { No } \\
\text { Yes }\end{array}$ & $\begin{array}{c}59.65(22.4) \\
58.85(22.27)\end{array}$ & 0.79 \\
\hline $\begin{array}{l}\text { Supplement regimen: } \\
\text { Monthly } \\
\text { Quarterly }\end{array}$ & $\begin{array}{c}58.2(22.2) \\
60.35(22.25)\end{array}$ & 0.52 \\
\hline Continuous variables & Correlation coefficient (SD) & p \\
\hline PTH & $-0.102(0.51)$ & $<0.05$ \\
\hline $\mathrm{Ca}$ & $2,515(1.10)$ & 0.94 \\
\hline
\end{tabular}

with mobility problems and/or on antiepileptic medication [3]. Most people cared for by the Uliazpi Foundation are residents, many of them with severe mobility problems, and $44 \%$ receive antiepileptic medication; and, hence, they represent an at risk group.

The absence of rickets or osteomalacia no longer being considered sufficient to assess the adequacy of vitamin $\mathrm{D}$ intake, currently all the guidelines are based on biochemical criteria, in particular, measurements of the forms of calcidiol. The levels in the assumed healthy population range from 25 to $100 \mathrm{nmol} / \mathrm{L}$ [4]. There is no consensus, however, except in very general terms, on what levels are adequate. Levels set on the basis of what is necessary to reduce the absorption of $\mathrm{Ca}$ in the intestine is estimated to be as little as $10 \mathrm{nmol} / \mathrm{L}$ [5]. Alternatively, when the goal is reducing the risk of fractures, levels of over $75 \mathrm{nmol} / \mathrm{L}$ have been indicated [6]. To sum up, opinion is divided between those who recommend levels of $50-\mathrm{nmol} / \mathrm{L}$ and those who recommend levels of $75-125 \mathrm{nmol} / \mathrm{L}$. A recent publication from a group of experts on the subject indicates that levels under $50 \mathrm{nmol} / \mathrm{L}$ are clearly pathological. Applying this threshold to the Spanish population, they reach to the striking conclusion that $30 \%$ of young people and $87 \%$ of institutionalized elderly people have vitamin D insufficiency [7]. At the opposite extreme, it has been estimated that levels above around 1000-1250 nmol/L may cause adverse effects [8], although some authors recommend not exceeding $125 \mathrm{nmol} / \mathrm{L}$ given that some studies have reported the intake of large doses having been followed by an increase in the rate of fractures [9]. The laboratory of our referral hospital considers levels of under $30 \mathrm{nmol} / \mathrm{L}$ to be deficient, $30-75 \mathrm{nmol} / \mathrm{L}$ to be insufficient and above $75 \mathrm{nmol} / \mathrm{L}$ to be normal.

The preparation, doses and regimen of administration used vary greatly. The generally accepted 
Table 3: Different Cholecalciferol Administration Regimens, and Results Including Serum Levels of 25(OH)D at the End Points of the Studies

\begin{tabular}{|c|c|c|c|c|}
\hline Author & Objective & Population & Dosage & Results including final 25(OH) D levels \\
\hline $\begin{array}{c}\text { Chel, V. } \\
\text { et al. (2008) }\end{array}$ & $\begin{array}{l}\text { To determine } \\
\text { whether the } \\
\text { same total } \\
\text { amount of } \\
\text { vitamin D } \\
\text { administered } \\
\text { in different } \\
\text { ways was } \\
\text { effective }\end{array}$ & $\begin{array}{l}338 \text { people } \\
\text { living in care } \\
\text { homes: } \\
76 \text { men } \& \\
262 \text { women; } \\
\text { Age: } 84 \pm \\
6.3 \text { years }\end{array}$ & $\begin{array}{l}-600 \mathrm{IU} / \text { day or } \\
\text { placebo } \\
-4,200 \mathrm{IU} / \text { week or } \\
\text { placebo } \\
-18,000 \mathrm{IU} / \text { month or } \\
\text { placebo } \\
\text { for } 4 \text { months }\end{array}$ & $\begin{array}{l}\text { Significant differences between the placebo and the other } \\
\text { groups }(p<0.001) \text {, between the daily and weekly intake groups } \\
(p=0.01) \text { and between the daily and monthly intake groups } \\
\text { ( } p<0.001) \\
\text { Final values Mean }(\mathrm{SD}) \text { : } \\
\text { In the placebo group: } 25,5(12) \mathrm{nmol} / \mathrm{L} / \mathrm{ml} \\
\text { In the daily intake group: } 69,9(17,8) \mathrm{nmol} / \mathrm{L} \\
\text { In the once a week intake group: } 67,2(14) \mathrm{nmol} / \mathrm{L} \\
\text { In the once a month intake group53.1 }(15,9) \mathrm{nmol} / \mathrm{mL}\end{array}$ \\
\hline $\begin{array}{l}\text { Trivedi, D.P } \\
(2003)\end{array}$ & $\begin{array}{l}\text { To assess the } \\
\text { relationship of } \\
\text { fractures and } \\
\text { mortality with } \\
\text { vitamin D } \\
\quad \text { levels }\end{array}$ & $\begin{array}{l}2686 \\
\text { people: } \\
2037 \text { men \& } \\
649 \text { women; } \\
\text { Age range: } \\
65-85 \text { years; } \\
\text { General } \\
\text { population }\end{array}$ & $\begin{array}{l}100,000 \text { every } 4 \\
\text { months for } 5 \text { months }\end{array}$ & $\begin{array}{c}\text { A lower rate of fractures in the vitamin } D \text { group than the placebo } \\
\text { group (RR: } 0.78 \text { [0.61-0.99]) but no difference in mortality (RR: } \\
0.88(0.74-1.06) p=0.18) \text {. } \\
\text { Final vitamin levels were higher in those taking vitamin } D \text { than in } \\
\text { the placebo group }(p<0.001) \text { : Mean }(S D) \\
\text { - Vitamin group: } 74,3(20,7) \mathrm{nmol} / \mathrm{L} \\
\text { - Placebo group: } 53,4(21,1) \mathrm{nmol} / \mathrm{L}\end{array}$ \\
\hline $\begin{array}{l}\text { Bacon, C.J. } \\
(2009)\end{array}$ & $\begin{array}{l}\text { To assess } \\
\text { whether there } \\
\text { were } \\
\text { differences in } \\
\text { efficacy with } \\
\text { different } \\
\text { administration } \\
\text { regimens }\end{array}$ & $\begin{array}{l}63 \text { elderly } \\
\text { people }\end{array}$ & $\begin{array}{l}-500,000 \mathrm{IU} \text { single } \\
\text { dose } \\
\text { - the same single dose } \\
+50,000 \mathrm{UI} / \text { month } \\
\text { - 50,000 IU/month } \\
\text { for } 3-5 \text { months }\end{array}$ & $\begin{array}{l}\text { After one month, levels increased by } 58 \pm 28 \mathrm{nmol} / \mathrm{L} \text { in the first } \\
\text { two groups, later falling gradually to } 69 \pm 5 \mathrm{nmol} / \mathrm{L} \text { and } 91 \pm 4 \\
\mathrm{nmol} / \mathrm{L} \text { in the first and second groups respectively. } \\
\text { In the third group, levels reached } 80 \pm 20 \mathrm{nmol} / \mathrm{L} \text { by } 3-5 \text { months. }\end{array}$ \\
\hline $\begin{array}{l}\text { Hackman, } \\
\text { K.L. (2010) }\end{array}$ & $\begin{array}{l}\text { To assess } \\
\text { whether there } \\
\text { were } \\
\text { differences in } \\
\text { efficacy with } \\
\text { different } \\
\text { administration } \\
\text { regimens }\end{array}$ & $\begin{array}{l}59 \text { people } \\
\text { with } 25(\mathrm{OH}) \\
D \text { levels }< \\
50 \mathrm{nmol} / \mathrm{L}\end{array}$ & $\begin{array}{l}-50,000 \mathrm{IU} / \text { day for } 10 \\
\text { days }+1,000 \text { IU } / \text { day } \\
\text { for } 60 \text { days } \\
-3,000 \mathrm{IU} / \text { day for } 30 \\
\text { days }+1,000 \text { IU/day } \\
\text { for } 60 \text { days }\end{array}$ & $\begin{array}{c}\text { No significant differences between the } 2 \text { administration } \\
\text { regimens }(p=0.9) \text {. Mean }(\mathrm{Cl}) \\
55(40-69) \mathrm{nmol} / \mathrm{Lin} \text { the first group } \\
51(44-58) \mathrm{nmol} / \mathrm{L} \text { in the second group }\end{array}$ \\
\hline $\begin{array}{l}\text { Ish-Shalom } \\
(2008)\end{array}$ & $\begin{array}{l}\text { To explore } \\
\text { the effect on } \\
\text { levels of using } \\
\text { different } \\
\text { administration } \\
\text { regimens }\end{array}$ & $\begin{array}{l}\text { Women who } \\
\text { underwent } \\
\text { surgery for } \\
\text { femur } \\
\text { fracture }\end{array}$ & $\begin{array}{l}-1,500 \mathrm{IU} / \text { day } \\
-10,500 \mathrm{IU} / \text { week } \\
-45,000 \mathrm{IU} / 28 \text { days } \\
\text { for } 2 \text { months }\end{array}$ & $\begin{array}{l}\text { In all } 3 \text { groups levels increased significantly from baseline } \\
\qquad \begin{array}{c}(p<0.001) \\
\text { No significant differences between the } 3 \text { groups. } \\
\text { Final values } \\
-32,2(8,5) \mathrm{ng} / \mathrm{ml} \text { in the daily regimen } \\
-29,2(8,9) \mathrm{ng} / \mathrm{ml} \text { in the weekly regimen } \\
-37.1(10.3) \mathrm{ng} / \mathrm{ml} \text { in the monthly regimen }\end{array}\end{array}$ \\
\hline $\begin{array}{c}\text { Khaw, K.T } \\
(1994)\end{array}$ & $\begin{array}{l}\text { To assess } \\
\text { whether a } \\
\text { single dose of } \\
\text { cholecalciferol } \\
\text { reduced PTH } \\
\text { concentration }\end{array}$ & $\begin{array}{l}138 \text { healthy } \\
\text { adults of } \\
\text { both sexes } \\
\text { living in the } \\
\text { community; } \\
\text { aged: } 63-76 \\
\text { years }\end{array}$ & $\begin{array}{l}\text { Single dose of } 100,000 \\
\text { IU compared to } \\
\text { placebo }\end{array}$ & $\begin{array}{c}\text { After } 5 \text { weeks, the levels of PTH were lower in the placebo } \\
\text { group }(\mathrm{p}<0.0001) \text {, and the levels of } 25(\mathrm{OH}) \mathrm{D} \text { were } 60 \% \text { higher } \\
\text { in the treated group }(14.1 \mathrm{ng} / \mathrm{ml}[6.2]) \text { than in the placebo group } \\
(13.4 \mathrm{ng} / \mathrm{ml}[5.6])(\mathrm{p}<0.001) .\end{array}$ \\
\hline $\begin{array}{l}\text { Kilpinen- } \\
\text { Loisa, P. } \\
\text { (2009) }\end{array}$ & $\begin{array}{l}\text { To determine } \\
\text { the vitamin } D \\
\text { levels and to } \\
\text { assess the } \\
\text { results of } 2 \\
\text { different } \\
\text { administration } \\
\text { regimens }\end{array}$ & $\begin{array}{l}138 \text { adults: } \\
95 \text { men and } \\
43 \text { women, } \\
\text { with } \\
\text { intellectual } \\
\text { disabilities } \\
\text { who were } \\
\text { care home } \\
\text { residents }\end{array}$ & $\begin{array}{l}\text { - } 800 \text { IU/day p.o. for } 6 \\
\text { months } \\
\text { - single dose } 150,000 \\
\text { IU i.m. }\end{array}$ & $\begin{array}{l}\text { In both cases there were significant differences from baseline } \\
(p<0.001) \text {. Levels were significantly higher in the group taking } \\
\text { the regular oral dose than those given a single intramuscular } \\
\text { dose }(p<0.001 \text {. Mean(SD)) } \\
-82(21) \mathrm{nmol} / \mathrm{L} \text { in those with daily dose (p.o.) } \\
-62 \text { 15) nmol/L in those receiving a single dose (i.m.) }\end{array}$ \\
\hline
\end{tabular}


(Table 3). Continued.

\begin{tabular}{|c|c|c|c|c|}
\hline Author & Objective & Population & Dosage & Results including final 25(OH) D levels \\
\hline $\begin{array}{c}\text { Pekkarinen, } \\
\text { T. } \\
(2010)\end{array}$ & $\begin{array}{l}\text { To assess the } \\
\text { efficacy and } \\
\text { the safety of } 2 \\
\text { different } \\
\text { cholecalciferol } \\
\text { regimens }\end{array}$ & $\begin{array}{l}40 \text { women; } \\
\text { age: } 69.3 \text { - } \\
78.8 \text { years }\end{array}$ & $\begin{array}{l}\text { - } 800 \text { IU daily }+1 \mathrm{~g} \text { of } \\
\text { Ca } \\
-97.333 \mathrm{IU} \text { every } 4 \\
\text { months }+1 \mathrm{~g} \text { of } \mathrm{Ca} \\
\text { daily for a year }\end{array}$ & $\begin{array}{c}\text { The levels were higher in the group taking supplements daily } \\
\text { than in those taking them every } 4 \text { months }(p<0.0001) \text {. } \\
\text { Levels exceeded } 50 \mathrm{nmol} / \mathrm{L} \text { in all of those taking supplements } \\
\text { daily and } 67 \% \text { of those taking them every } 4 \text { months. } \\
\text { Levels exceeded } 75 \mathrm{bmol} / \mathrm{L} \text { in } 47 \% \text { of those taking the } \\
\text { supplements daily and } 28 \% \text { of those taking them every } 4 \\
\text { months. }\end{array}$ \\
\hline $\begin{array}{l}\text { Sanders, } \\
\text { K.M. (2010) }\end{array}$ & $\begin{array}{l}\text { To assess } \\
\text { whether a } \\
\text { single dose of } \\
\text { vitamin } D \\
\text { reduces the } \\
\text { risk of falls } \\
\text { and fractures }\end{array}$ & $\begin{array}{l}2,256 \\
\text { women; age } \\
>70 \text { years } \\
\text { old; living in } \\
\text { their own } \\
\text { homes }\end{array}$ & $\begin{array}{l}\text { Single dose of } 500,000 \\
\text { IU in the autumn or } \\
\text { winter for } 3-5 \text { years } \\
\text { compared to placebo }\end{array}$ & $\begin{array}{c}\text { The rate of fractures was higher in the group given vitamin } D \\
\text { than in the controls (RR: } 1.15(1.02-1.30), p=0.03) \\
\text { In the vitamin } D \text { group, the levels reached } 120 \mathrm{nmol} / \mathrm{L} \text {, were } 90 \\
\text { nmol/L at } 3 \text { months and still higher than those in the placebo } \\
\text { group at } 12 \text { months. }\end{array}$ \\
\hline
\end{tabular}

Values are expressed means with SD and $95 \% \mathrm{Cl}$ (in parentheses). $\mathrm{RR}$ : relative risk.

recommendations are to give cholecalciferol by mouth, on a daily basis, at a dose between 700 and 1000 IU $[10,11]$. A range of other dosages, tested in the search for regimens that would be more convenient and improve treatment adherence, are summarised in Table $3[12-19,9]$.

Around $88 \%$ of individuals cared in our centres are on some type of medication, several drugs at the same time in most cases, and these are administered by staff providing direct healthcare. In general, we limit drugs taken to those that are strictly necessary and as far as possible avoid the use liquid formulations to be administered on a daily basis. For this reason, we assessed the effect of administering a formulation containing $20,000 \mathrm{IU}$ of calciferol per $10 \mathrm{ml}$ of solution, the only one of its type available in Spain, monthly or (three times the volume) quarterly.

The results observed represent a clear improvement, although it is not possible to quantify this given the lack of standardisation of the measurement of levels in years before the study. Whether the results should be judged as good or not depends on the criteria selected. If we consider that blood levels under $60 \mathrm{nmol} / \mathrm{L}$ may not reduce the risk of falls [20] or that of fractures [21], $60 \%$ of our patients would not have benefited. On the other hand, if we consider that levels above $50 \mathrm{nmol} / \mathrm{L}$ are adequate [22], $61.5 \%$ of patients met this criterion. Another factor to take into account is that the data related to fractures and falls in the general population cannot be extrapolated to this study population. In relation to this, Vanlint with a sample of 337 people with intellectual disability did not find any relationship between the levels of vitamin $D$ and bone fractures [22].
We have not identified any explanation for the difference found between the two centres in San Sebastián and the Fraisoro and Zubieta centres. Apart from potential differences in adherence to treatment between centres, the only factor we have data on that might have an impact is the higher percentage of wheelchair users in the first two (43 and 27\%) compared to the other two (20 and 15\%) centres.

The association of epilepsy with metabolism bone disorders, and specifically with vitamin $D$, has been known since researchers identified cases of vitamin Ddependent rickets in children with intellectual disability and epilepsy treated with various combinations of phenobarbital, phenytoin, primidone and other drugs commonly used at the time [23]. Osteomalacic disorders have also been described in adults on monotherapy with phenytoin and valproic acid [24] and some studies with carbamazepine have shown a decrease in vitamin $D$ levels in patients unable to walk, though not in those able to walk [25], Further, it is still not known whether new antiepileptic drugs (gabapentin, lamotrigine and levetiracetam) have a similar effect [26]. In our series, we did not find any differences between those who received antiepileptic medication and those who did not considering all the antiepileptic drugs currently used. Interestingly, however, if we considered only those that can be classified as proven "sequestrants" (carbamazepine, phenobarbital, phenytoin, primidone and valproic acid), the mean level (SD) was significantly higher in those not on any of these drugs $(62,6 \mathrm{nmol} / \mathrm{L}(9.45))$ than in those taking them alone or in combination with other drugs $(53,6 \mathrm{nmol} / \mathrm{L}(7.58))(p=0.03)$.

We did not detect any differences between the two administration regimens, monthly or quarterly, and the 
difference between participants able to walk and wheelchair users was as would be expected, that is, higher in the former than the latter.

No adverse effects reported with either of the regimens. Given this, we propose that the routine practice should be to administer 60,000 IU of cholecalciferol every three months, and continue yearly testing, making adjustments as necessary on a caseby-case basis. In this way, we hope to minimize the cases of deficiency and improve on the current rate of users with levels above $50 \mathrm{nmol} / \mathrm{L}$. We believe that it is a reasonable and safe regimen to advocate, at least until there are more data, in particular, from further studies specific to the population we care for and with longer follow-up periods.

\section{CONCLUSIONS}

The administration of 60,000 IU of cholecalciferol orally every three months for a year decreased the percentage of individuals with deficient levels of vitamin $\mathrm{D}$ to $3.5 \%$, and increased that with levels greater than or equal to $50 \mathrm{nmol} / \mathrm{L}$ to $62.5 \%$ with no reports of adverse effects or known risks. We believe that this is a reasonable policy to propose to the families and legal guardians of the individuals under our care and that by adopting this approach we will meet objectives that, though they could seem rather unambitious, we consider adequate; it should be borne in mind that levels observed in this population are considered a biochemical indicator of a risk but have not, as far as we are aware, been directly associated with any health problems. Ongoing annual health check-ups will indicate whether this policy should be altered.

\section{REFERENCES}

[1] Wacker M, Holick MF. Vitamin D - effects on skeletal and extraskeletal health and the need for supplementation. Nutrients 2013; 5(1): 111-48. http://dx.doi.org/10.3390/nu5010111

[2] Balion C, Griffith LE, Strifler L, Henderson M, Patterson C, Heckman G, et al. Vitamin D, cognition and dementia: a systematic review and meta-analysis. Neurology 2012; 79(13): 1397. http://dx.doi.org/10.1212/WNL.0b013e31826c197f

[3] Pearce SH, Cheetham TD. Diagnosis and management of vitamin D deficiency. BMJ 2010; 340: b5664-c111. http://dx.doi.org/10.1136/bmj.b5664

[4] Coombs GFJ. Vitamin D. In: Elsevier Academic Press, editor. The Vitamins. Third ed. Burlington: Elsevier 2008; pp. 14579.

[5] Need AG, O'Loughlin PD, Morris HA, et al. Vitamin D metabolites and calcium absorption in severe vitamin $D$ deficiency. J Bone Miner Res 2008; 23(11): 1859-63. http://dx.doi.org/10.1359/jbmr.080607
[6] Holick MF. Vitamin D deficiency. N Engl J Med 2007; 357(3): 266-81.

http://dx.doi.org/10.1056/NEJMra070553

[7] Gómez de Tejada M, Sosa Henríquez M, et al. Documento de posición sobre las necesidades y niveles óptimos de vitamina D. Rev Osteoporos Metab Miner 2011; 3(1): 53-64.

[8] Gertner JM, Domenech M. 25-Hydroxyvitamin D levels in patients treated with high-dosage ergo- and cholecalciferol. J Clin Pathol 1977; 30(2): 144-50. http://dx.doi.org/10.1136/jcp.30.2.144

[9] Sanders KM, Stuart AL, Williamson EJ, et al. Annual highdose oral vitamin $D$ and falls and fractures in older women: a randomized controlled trial. JAMA 2010; 303(18): 1815-22. http://dx.doi.org/10.1001/jama.2010.594

[10] Dawson-Hughes B, Heaney RP, Holick MF, et al. Estimates of optimal vitamin D status. Osteoporos Int 2005; 16(7): 7136.

http://dx.doi.org/10.1007/s00198-005-1867-7

[11] Tang BM, Eslick GD, Nowson C, et al. Use of calcium or calcium in combination with vitamin $D$ supplementation to prevent fractures and bone loss in people aged 50 years and older: a meta-analysis. Lancet 2007; 370(9588): 657-66. http://dx.doi.org/10.1016/S0140-6736(07)61342-7

[12] Chel V, Wijnhoven HA, Smit JH, et al. Efficacy of different doses and time intervals of oral vitamin $D$ supplementation with or without calcium in elderly nursing home residents. Osteoporos Int 2008; 19(5): 663-71. http://dx.doi.org/10.1007/s00198-007-0465-2

[13] Trivedi DP, Doll R, Khaw KT. Effect of four monthly oral vitamin D3 (cholecalciferol) supplementation on fractures and mortality in men and women living in the community: randomised double blind controlled trial. BMJ 2003; 326(7387): 469.

http://dx.doi.org/10.1136/bmj.326.7387.469

[14] Bacon CJ, Gamble GD, Horne AM, et al. High-dose oral vitamin D3 supplementation in the elderly. Osteoporos Int 2009; 20(8): 1407-15. http://dx.doi.org/10.1007/s00198-008-0814-9

[15] Hackman KL, Gagnon C, Briscoe RK, et al. Efficacy and safety of oral continuous low-dose versus short-term highdose vitamin D: a prospective randomised trial conducted in a clinical setting. Med J Aust 2010; 192(12): 686-9.

[16] Ish-Shalom S, Segal E, Salganik T, et al. Comparison of daily, weekly, and monthly vitamin D3 in ethanol dosing protocols for two months in elderly hip fracture patients. $J$ Clin Endocrinol Metab 2008; 93(9): 3430-5. http://dx.doi.org/10.1210/jc.2008-0241

[17] Khaw KT, Scragg R, Murphy S. Single-dose cholecalciferol suppresses the winter increase in parathyroid hormone concentrations in healthy older men and women: a randomized trial. Am J Clin Nutr 1994; 59(5): 1040-4.

[18] Kilpinen-Loisa P, Arvio M, Ilvesmaki V, et al. Vitamin D status and optimal supplementation in institutionalized adults with intellectual disability. J Intellect Disabil Res 2009; 53(12): 1014-23.

http://dx.doi.org/10.1111/j.1365-2788.2009.01218.x

[19] Pekkarinen T, Valimaki VV, Aarum S, et al. The same annual dose of 292000 IU of vitamin D (cholecalciferol) on either daily or four monthly basis for elderly women: 1-year comparative study of the effects on serum 25(OH)D concentrations and renal function.Clin Endocrinol (Oxf) 2010; 72(4): 455-61. http://dx.doi.org/10.1111/j.1365-2265.2009.03637.x

[20] Bischoff-Ferrari HA, Dawson-Hughes B, Staehelin HB, et al. Fall prevention with supplemental and active forms of vitamin D: a meta-analysis of randomised controlled trials. BMJ 2009; 339: b3692-445

http://dx.doi.org/10.1136/bmj.b3692 
[21] Bischoff-Ferrari HA, Willett WC, Orav EJ, et al. A pooled analysis of vitamin $D$ dose requirements for fracture prevention. N Engl J Med 2012; 367(1): 40-9. http://dx.doi.org/10.1056/NEJMoa1109617

[22] Vanlint S, Nugent M. Vitamin D and fractures in people with intellectual disability. J Intellect Disabil Res 2006; 50(Pt 10): 761-7.

http://dx.doi.org/10.1111/j.1365-2788.2006.00841.x

[23] Lifshitz F, Maclaren NK. Vitamin D-dependent rickets in institutionalized, mentally retarded children receiving longterm anticonvulsant therapy. I. A survey of 288 patients. J Pediatr 1973; 83(4): 612-20. http://dx.doi.org/10.1016/S0022-3476(73)80223-9

[24] Krishnamoorthy G, Nair R, Sundar U, et al. Early predisposition to osteomalacia in Indian adults on phenytoin or valproate monotherapy and effective prophylaxis by simultaneous supplementation with calcium and 25-hydroxy vitamin $\mathrm{D}$ at recommended daily allowance dosage: a prospective study. Neurol India 2010; 58(2): 213-9. http://dx.doi.org/10.4103/0028-3886.63796

[25] Lamberg-Allardt C, Wilska $M$, Saraste $K L$, et al. Vitamin $D$ status of ambulatory and nonambulatory mentally retarded children with and without carbamazepine treatment. Ann Nutr Metab 1990; 34(4): 216-20. http://dx.doi.org/10.1159/000177590

[26] Bartl R. Antiepileptic drug-induced osteopathy. Subtypes, pathogenesis, prevention, early diagnosis and treatment. Dtsch Med Wochenschr 2007; 132(27): 1475-9. http://dx.doi.org/10.1055/s-2007-982057

DOI: http://dx.doi.org/10.6000/2292-2598.2014.02.01.6

(C) 2014 Zabalza et al.; Licensee Lifescience Global.

This is an open access article licensed under the terms of the Creative Commons Attribution Non-Commercial License (http://creativecommons.org/licenses/by-nc/3.0/) which permits unrestricted, non-commercial use, distribution and reproduction in any medium, provided the work is properly cited. 